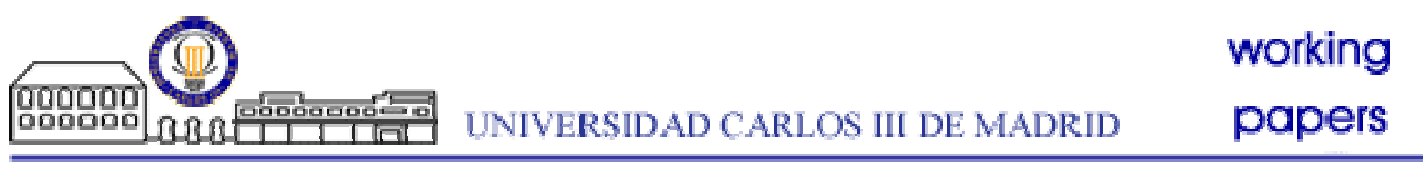

Working Paper 08-57

Business Economic Series 13

November 2008
Departamento de Economía de la Empresa Universidad Carlos III de Madrid

Calle Madrid, 126

28903 Getafe (Spain)

Fax (34-91) 6249607

\title{
The gap between male and female pay in the Spanish tourism industry
}

\author{
Fernando Muñoz-Bullón ${ }^{1}$
}

\begin{abstract}
This paper analyzes wage differentials between male and female workers in the Spanish tourism industry, using a large, administratively matched employer-employee data set obtained from a representative sample of companies. This allows us to control for unobserved firm-specific factors likely to affect the magnitude of the gender wage gap. Our findings indicate that male workers earn on average $6.7 \%$ higher monthly wages than their socially comparable female counterparts. In particular, the type of contract held, the qualifications required for the job and the specific sub-sector of employment are very important variables in explaining this gender wage difference. We also find that only around $12 \%$ of the mean wage difference in the tourism industry cannot be explained by differences in observable characteristics, which is well below the average for the rest of the industries in Spain (87\%). Our interpretation is that minimum wage legislation provides a particularly effective protection to women in the tourism industry, which is characterized by a large number of low-wage earners.
\end{abstract}

Keywords: Spanish tourism industry, Wage discrimination, Blinder-Oaxaca decomposition, Censored models

JEL Classification: C34, J16, J31, J71

\footnotetext{
${ }^{1}$ Sección de Organización de Empresas. Universidad Carlos III de Madrid. C/ Madrid, 126. 28903 Getafe (Madrid). SPAIN. E- mail: fernando.munoz@uc3m.es
} 


\section{Introduction}

Since the early 1960s, tourism has become the principal engine of growth in the services sector in Spain. It has played a key role both as an income generator and as a source of employment, growing at twice as much as the national Gross Domestic Product growth rate. According to the Spanish Labour Force Survey (LFS) - a quarterly, continuous, sample-based survey directed at households and produced by the National Statistics Institute - the employees in tourism accounted for $12 \%$ of the working population at the national level and 19\% of services employees in 2003 . Despite this, tourism employment has not yet been the subject of widespread academic analysis in Spain, in contrast to other countries with a comparable standard of living. More specifically, previous research has largely neglected issues of gender wage differentials. This paper focuses on the factors that contribute to wage differences between male and female workers in the Spanish tourism industry when compared to other industries. The Spanish case is of interest because tourism jobs are often perceived as (a) requiring low levels of entry qualification, and (b) paying low wages. Thus it is not surprising if employment in this industry generally does not enjoy high status. Our results are useful for understanding how well labour markets work in tourism and non-tourism industries, and for understanding gender inequality. For this purpose, we use a large, administratively matched employer-employee data set that contains a representative sample of companies in Spain. The data set collects data on the monthly wages of workers employed in these companies during a 6-year interval (from 1998 to 2003). This data set is uniquely suited to explaining wage differences among workers hired by the same company, since it includes the individual labour history of every worker hired by the sample companies. No other data set in Spain currently meets this criterion. Without it, gathering comparable data from every worker hired by a representative sample of companies in this country simply would not have been feasible. 
Our work is mainly descriptive. We establish the main features of the wage gap, its decomposition, and trace some underlying patterns (e.g., which groups of women face particularly small or large wage differentials). Economists have many theories of why women are paid less than men (see, for example, Cain, 1986). While we do find that female workers in tourism (and non-tourism) industries are paid less than men, our findings have no particular bearing on the validity of the various theories. Moreover, the wage difference alone may not accurately reflect the women's economic wellbeing relative to men. With all these limitations in mind, we take the modest first step of documenting the female earnings gap in the Spanish tourism industry.

Our main findings indicate that male workers in tourism earn on average around $6.7 \%$ higher monthly wages than their socially comparable female counterparts (for nontourism workers this gap is $4.81 \%$ ). Among tourism workers, most of this gap is due to the type of contract held, the qualifications required for the job and the specific subsector of employment. In addition, our decomposition results reveal that only $12 \%$ of the gender wage gap in tourism can be attributed to gender-specific differences in returns to market skills (while for non-tourism workers this proportion rises to $87.49 \%$ ). We therefore conclude that even though the gender wage gap is slightly wider among tourism workers than among non-tourism workers, minimum wage legislation in Spain (introduced in 1964) provides a more effective protection to women in the tourism industry, which is characterized by a higher proportion of lowwage earners.

The rest of this article is organized as follows. Section 2 provides an overview of the main characteristics of the labour market in Spain. Section 3 provides a survey of the relevant literature on the gender wage gap in tourism industries. Section 4 takes a first descriptive look at the data. Section 5 presents the econometric model, and Section 6 presents the empirical results. Finally, Section 7 contains concluding remarks. 


\section{A brief overview of the structural characteristics of the labour market in Spain}

From the late 1970s to the end of the 1990s, the Spanish economy was affected by mass unemployment and an inflation differential with the rest of the European Union (EU). Economists generally agreed that the malfunctioning labour market was to blame for Spain's high level of unemployment, and this consensus prompted a series of reforms (beginning in the 1980s) aimed at reducing dismissal costs, limiting the use of temporary contracts and increasing the incentives for firms to hire workers from certain population groups using open-ended contracts. Although the economy generally improved from the late $1990 \mathrm{~s}^{2}$, the evidence suggests that the labour reforms have done little to reduce the proportion of temporary employment: despite the government's best efforts, only one in three contracts is permanent. As a result, Spain has the largest proportion of fixed-term contracts in Europe. This widespread use of fixed-term contracts may affect the gender wage gap if fixed-term contracts have uneven effects on the pay structures of men and women (Amuedo-Dorantes \& De la Rica, 2006). Indeed, the unions point to this high rate of temporary employment and an insufficient fall in unemployment as the main problems of the Spanish labour market. They have particularly affected women, even though there has been an increase in women's activity rates during the last two decades (de la Rica et al., 2008). As a result, Spain has one of the poorest records among the advanced economies for incorporating women into its labour force.

Over the last four decades the structure of employment in Spain has gradually approached that of the advanced European economies. The agricultural workforce declined sharply, down to under 1 million in the late 1990s from 4 million 30 years earlier. Restructuring and technological change have contributed to cutting the number of jobs in the secondary sector. The employment haemorrhage was most acute in "old"

\footnotetext{
${ }^{2}$ The employment rate increased by $2-7 \%$ after 1995 , reaching $42.46 \%$ in 1999 according to the Labour Force Survey. Meanwhile, the unemployment rate fell by $3.9 \%$, reaching $15.90 \%$ in 1999, and the activity rate increased by $1 \%$, reaching $50.29 \%$ in 1999 .
} 
industries such as textiles, steel, shipbuilding and engineering (Castro et al., 1999). The exception to the overall drop in employment has been the services sector. This sector has benefited from the continued prominence of Spain as a major world tourist destination, state sponsorship of the welfare state, and a boom in administrative jobs. As regards women, female employment is concentrated in two main areas: manufacturing (primarily in the textile, leather and footwear industries) and services (retailing, hotels, education and domestic service). Typically, in industries in which women constitute the majority the jobs are part-time, low paid and insecure.

Consequently, as the female participation rate has risen $^{3}$, unemployment has become increasingly "feminized" (Threlfall, 2000).

Finally, inequalities exist in pay rates between men and women (Corkhill, 2004).

Although the Workers' Charter was amended in the 1990s to secure the principle of equal pay for women - employers are legally obliged to pay the same wage for equal work, with no discrimination whatsoever on grounds of sex - much remains to be achieved with regard to equality of opportunity, particularly childcare provision and other measures to reconcile family life (Threlfall, 2000).

\section{Gender pay differences in tourism employment}

The use of the term tourism employment needs some clarification, as tourism is not a recognized industry in the Standard Industrial Classification, and most countries' national accounts do not list tourism as a separate entity (Cooper et al., 1993). This is because while tourism contains a wide variety of businesses, it is not an industry in the traditional sense of the word. So it does not fit the standard criteria for (national) accounts ${ }^{4}$. In our definition of the tourism industry from a supply-side perspective, the

\footnotetext{
${ }^{3}$ There has been a steady growth in Spanish female participation from $27 \%$ in 1985 to $46.95 \%$ in 2005 , according to the LFS. This is, however, well below the average female participation rate in the EU in $2005(56.3 \%)$.

${ }^{4}$ In most statistical systems, the best approximation we can get on tourism (and especially on tourism employment) is obtained from the restaurant and catering entry. This is due to the fact that tourism is seen as an industry dominated by the hospitality sector. But tourism is a multi-product industry with strong links to other economic sectors (Diamond, 1977).
} 
classification according to the industry (i.e., the main economic activity of the company) will be used (see next section) ${ }^{5}$.

The gap between the average pay of men and women in all industrialized countries is perhaps the clearest indication of the inequality that is a universal feature of female employment (Doherty \& Stead, 1998). For the tourism industry, Kinnaird \& Hall (1994), Wilkinson \& Pratiwi (1995), and Sinclair (1997) establish the conceptual framework for analyzing gender issues in tourism. These authors note the scarce literature on gender wage differences in this industry in the 1990s, despite the fact that tourism is an important source of employment in some countries. While to our knowledge there are no empirical studies on this issue in Spain $^{6}$, gender wage differences in tourism employment have been analyzed in different settings at the international level after the year 2000. Apart from pure gender discrimination-for instance, in the United States Sparrow \& Iverson (1999), after taking into account the effect of legitimate causes (such as human capital), find persistence in gender-based income disparity in the hospitality industry — explanations for the existence of differential earnings between men and women include occupational segregation, the concentration of low pay in certain industries, and human capital theory.

As regards occupational segregation, previous studies have offered evidence to suggest that women's employment is both horizontally and vertically segregated, with the majority of female workers located in subordinate posts, receiving lower levels of

\footnotetext{
${ }^{5}$ Defining tourism from a supply-side perspective is somehow problematic, since tourists spend money on a variety of products and services and so tourism cuts through the normal classification of industries. However, defining tourism from a demand-side perspective would only provide insight into the number of jobs in the tourism industry, not into the characteristics of the labour force. To say something about these characteristics (wages, immigrant status, age, etc.) some kind of supply-side approach must be used.

${ }^{6}$ In Spain, interest in wage differences by gender is a result of the relatively recent rise in female labour force participation rates (as indicated in Section 2). Recent studies in this area for the whole Spanish economy include Amuedo \& De la Rica (2006), Caparros et al. (2004), De la Rica et al. (2008), De la Rica \& Ugidos (1995), Dolado et al. (2004), García et al. (2001), Gardeazábal \& Ugidos (2005) and Hernández $(1995,1996)$.
} 
remuneration (Richter, 1995; Groshen, 1991; Sorensen, 1989) ${ }^{7}$. The tourism industry also segregates women into areas of employment that commercialize their perceived domestic skills and "feminine" characteristics (Enloc, 1989; Kinnaird, Kothari \& Hall, 1994). For instance, Delfim \& Varejao (2007) find evidence of vertical segregation in the tourism industry in Portugal. Women do hold some managerial positions in the tourism industry, but typically even these posts are gender segregated (Skalpe, 2007). A second explanation for gender-based differences concerns the structural concentration of low pay in certain industries. Rubery \& Fagan (1994) draw together evidence from all EU member states to show that women are more vulnerable to low pay than men. This is not only because of women's occupational segregation within industries and their propensity to experience part-time or home working (see below), but also because of their tendency to work in low-paying industries. Broadly speaking, tourism pay is relatively low (Riley, Ladkin \& Szivas, 2002) —wage levels are generally $20 \%$ below the EU average, and even when enhanced rates for overtime exist, they may be rarely paid (Royle, 1999) ${ }^{8}$. This lower level of pay relative to other industries is likely to be so not only because human capital requirements are low in tourism (relative to other industries), and the skills required are easily acquired (Riley \& Szivas, 2003). In addition, tourism workers are unlikely to be able to use organization-specific human capital to improve earnings by staying on to take advantage of the organization's need to keep them for their acquired specific skills (Mincer \& Jovanovic, 1981). Two reasons may explain this. On the one hand, employers pay less for a job where tenure will be short because of the consequent learning and advancement process. Rosen (1972) points out that the capacity of a job to teach has a downward effect on the rate of pay. He argues that certain jobs are seen

\footnotetext{
${ }^{7}$ Stockdale (1991) defines this segregation as follows: "The jobs that women do are different from those done by men (horizontal segregation) and women work at lower levels than men in the occupational hierarchy (vertical segregation)".

${ }^{8}$ Working conditions in the EU tourism industry include potentially problematic areas such as irregular working hours, frequent Sunday working, wages without a fixed element in $25 \%$ of cases, and widespread absence of overtime premiums.
} 
as opportunities to learn and thus employers assume short tenure and offer a rate that represents the role the job is playing in a recognized career progression. On the other hand, productivity in tourism is not strongly related to job tenure - as a result of the fact that the skills required are easily acquired (i.e., there is little incentive/reward structure). Many of these low-paid occupations in tourism are conspicuously populated by women and intra-occupational differentials often favour men (Sparrow \& Iverson, 1989). In any case, the fact that high proportions of the occupants of these low-paid jobs are women does not cause the level of pay, thus tempering the discrimination argument and pointing the finger at the nature of the jobs (Murgatroyd, 1982).

Gender-based differences caused by occupational segregation and the concentration of low pay in tourism industries are evidence of structural factors beyond the control of the individual. In contrast, according to the third explanation for gender-based differences - human capital theory-education leads to greater productivity in the workforce, and so increases the market value of labour (Becker, 1962), because education provides the workers with skills that their employers value. As a result, an individual's pay is primarily attributable to acquired education and experience. The implication is that — contrary to what happens in the other two explanations - women can and should obtain more education and experience to achieve income parity with men. However, women accumulate less human capital (education, training, experience) than men because they spend fewer years in the labour force-women allocate a greater proportion of their time to raising children — and have different expectations of market participation than men (Mincer \& Polachek, 1974) ${ }^{9}$. Thus the choices and preferences of women may also explain occupational segregation: women choose jobs that require less human capital because they believe they will spend fewer years in the labour market than men. In turn, employers assume that women will have a lower degree of attachment to the firm than men, and prefer to train and promote

\footnotetext{
${ }^{9}$ Further evidence suggests a close connection between career interruptions and earnings growth for women (Corcoran \& Duncan, 1979; Cox, 1984; Joshi, 1984; Mincer \& Ofek, 1982).
} 
male workers who work continuously. Hence productivity differentials between men and women appear and their pay may merely reflect this.

\section{A first look at the data}

The estimation of wage equations requires worker-level data. To control for both worker and workplace characteristics matched employer-employee data are also required. Thus we use a Spanish data set having these two properties. It was constructed from Social Security records as follows. The companies included are a 1percent representative random sample of the companies belonging to the General Regime of the Social Security system on 31 December $2000^{10}$. We have access to the 6-year labour history in these companies - from 1998 to 2003 - of the individuals who were employed by them from 31 December 2000 to 31 December 2003. This is the only data set in Spain where the labour history of every worker employed at these companies is available. This allows us to explain wage differences among workers employed at the same company by taking into account the panel-level variance component (see Section 5.1 below $^{11}$ ). The data are not restricted to the tourism industry, but cover all the other industries too. They include firm characteristics such as industry, location and size (measured by the size of the workforce). For each worker, data is available on gender, age, date of admission to the firm, monthly wages, the type of contract held ${ }^{12}$, job tenure, the qualifications required for the job, and whether or not the individual is an immigrant. The following two limitations are worth noting. First, this data set does not include the educational level, which would measure the individuals' human capital independent of their job. Because of this, the

\footnotetext{
${ }^{10}$ Registration with the Social Security is obligatory for all workers. Individuals are registered when they begin their working life and are included under one of the Social Security schemes. There are three regimes: the "General Social Security Scheme" (Régimen General de la Seguridad Social, or RGSS), the "Special Social Security Schemes" (Regímenes Especiales de la Seguridad Social, or RESS), and the Government employees' scheme (Régimen de Clases Pasivas, or RCP).

${ }^{11}$ As explained in sections 5.1 and 5.2, including firm effects allows us to isolate a part of the unexplained wage gap which might be due to variable omissions.

${ }^{12}$ See Table B in the Appendix for definitions of each type of temporary contract. For more details of each type of contract, see the Guía Laboral, elaborated by the Spanish Ministry of Labour and Social Affairs, which is freely available from the following website: http://www.mtas.es.
} 
qualification level is used as a proxy for the individual skill level (as it captures a mix of the occupation and the educational level required for the job). Second, the individual's total experience in the labour market is missing, since the available data refer to the 6-year labour history at the companies included in the sample (as explained above $)^{13}$. Thus we use age as a proxy for experience in the labour market.

Observations with incomplete data were excluded from the data set. Although this data set does not contain information about hours of work-so it is impossible to compute hourly wages ${ }^{14}$ - it is possible to distinguish between full-time and part-time workers through the type of contract variable. Thus we restrict the analysis to full-time employees between 16 and 65 years old (excluding the self-employed), which reduces sample heterogeneity. We identified the specific sub-sector where each worker is employed: (a) Hotels; (b) Camping sites and other commercial accommodation; (c) Restaurants, bars and canteens; (d) Transport, car hire, travel agencies, tour operators and tour guides; (e) Recreational, cultural and sporting facilities. The industries for non-tourism workers are shown in Table $\mathrm{C}$ in the Appendix. The whole sample was further divided by gender. Our sample selection criteria reduce the number of observations in the data set to 95,767 male and 77,379 female workers in tourism industries — 1,016 and 953 companies, respectively_ and to 130,850 male and 77,098 female workers in non-tourism industries - 6,512 and 5,007 companies, respectively. The variable of central interest is monthly wages from 1998 to $2003^{15}$. Since explicit information about hours of work is not available, the monthly Social Security

\footnotetext{
${ }^{13}$ As men and women are selected from the broader population (which includes those not working), sample selection issues arise when deriving the non-discriminatory wage structure. However, since the data set used has no information on people not working, it is not possible to correct for the non-random way in which individuals exercise their choice into paid employment. Thus the estimation of wage equations from samples of employed workers alone induces a sample selection bias. Not correcting for this selection bias may reduce the estimated gap (see Stanley \& Jarrell, 1998).

${ }^{14}$ Overtime work, however, is reflected in the Social Security contributions that are captured in the data set. In any case, a limitation would be encountered whenever differences between the real hours and the official hours exist.

${ }^{15}$ Although June and December are usually peak periods (and wages are therefore characterized by seasonality), this does not apply to contributions to Social Security, since extraordinary payments are pro-rated in such contributions. As regards non-tourism workers, we keep only the wage corresponding to the month of June of each year, due to the large size of this sub-sample.
} 
contributions (monthly wages, henceforth) are used as proxies (in constant 2003 euros). As the General Social Security Scheme establishes upper and lower bounds for monthly wages, the wage variable is censored. For this reason, we use a generalization of Oaxaca-Blinder's Decomposition Method in which censored data are taken into account (see Section 5.1 for a detailed description of this method).

\section{[TABLE 1]}

Tables 1 and 2 present gender wage differences in the main variables used for both tourism and non-tourism sub-samples, respectively. These tables also show differences in mean monthly wages (i.e., the raw gap), their significance levels, as well as the female-male ratios of mean wages. Among (non-)tourism workers, the female-male wage ratio is $85.23 \%(86.29 \%)$, which means that women's mean monthly wage is around 85 to $86 \%$ of men's, with very little difference between the two sub-samples. The econometric estimations - to be discussed in detail in the following section- seek to explain this gender-group difference in wages (i.e., whether it differs across socioeconomic, demographic and labour market related characteristics, and how much can be attributed to these characteristics). As Tables 1 and 2 indicate, there are obvious reasons for undertaking such an analysis, since the characteristics of females are not identical to those of men. In addition, the t-statistics show that most average wage differences between the sexes are statistically significant at conventional levels.

\section{[TABLE 2]}

As the tables show, female-male wage ratios fall in older workers: older women face a wider earnings gap than younger women. Thus market discrimination against females may persist for the older groups (while it decreases for the younger groups). Moreover, both among tourism and non-tourism workers gender segregation exists across subsectors. For instance, in tourism employment a higher proportion of women than men work in Hotels (49.89\% versus $43.62 \%$ ) and in Camping sites and other commercial accommodation (33.67\% versus $23.98 \%)$, but the reverse is true in Restaurants $(6.22 \%$ 
versus $24.49 \%$ ). Thus women are under-represented in the sub-sector where the highest wages are earned (Restaurants), and over-represented in the low-paid sectors (e.g., in Hotels and Camping sites and other commercial accommodation). As regards non-tourism workers, men are proportionately more present in Construction $(30.52 \%$ versus $2.41 \%$ ), and in Mining \& industry (24.68\% versus $16.84 \%$ ), whereas the opposite happens in Retailing, Computing and Health \& sanitation (see Table 2). Apart from industry segmentation, there exists evidence of vertical segmentation across qualification groups among tourism workers. A low level of qualifications is the hallmark characteristic of employment in this industry: the most important qualification level for males is semi-skilled clerks and skilled labourers (group 4), while that of females is semi-skilled and unskilled labourers (group 5)-Table A in the Appendix details the specific categories within each qualification group. Male workers are relatively more present in jobs requiring the highest qualification levels (where higher wages are earned: qualification groups 1 and 2): 10.97\% of male employees belong to these two groups, compared to only $6.08 \%$ of women. Among non-tourism workers, in contrast, the reverse is true (see Table 2).

While most tourism workers work in firms with less than or equal to 25 employees, female non-tourism workers work predominantly in firms with more than 100 workers. However, firm size is not markedly different between the sexes. Similarly, the distribution of tenure at the current job is rather similar across genders. But the proportion of contracts signed for less than one year is higher among tourism employees than among non-tourism workers. This suggests that employer-employee relationships are less stable in tourism than elsewhere in the economy. This instability is, however, not reflected in the type of contract, since the proportion of individuals hired under open-ended contracts is on average higher among tourism workers than among non-tourism workers. This may be attributed to the existence of a special type of open-ended contract called 'discontinuous open-ended contract' (in Spanish, 
contrato fijo discontinuo), which allows for interruptions of the labour relation due to seasonality. These interruptions (typically, in autumn and winter) are covered either by working elsewhere (for example, in construction) or by receiving unemployment benefit. In other words, when each tourist season ends, workers hired under discontinuous open-ended contracts may be laid off, but they expect an implicit re-call by the same firm in the following tourist season. Finally, among temporary contracts, the casual (Per-task) contract is the most widespread among (non-)tourism workers.

\section{[FIGURE 1]}

Figures 1 and 2 show empirical density functions (estimated using kernel density estimates) by gender, for tourism and non-tourism workers, respectively. The figures show that the wage distribution of male workers is more skewed to the right than that of female employees. Thus more men than women are breaking into the highestpaying jobs. The percentage of men and women whose log earnings are more than one standard deviation above the overall mean log earnings in tourism is $26.61 \%$ and $13.78 \%$, respectively. The figures for non-tourism workers are $22.46 \%$ and $14.47 \%$, respectively. Thus as expected, substantially more men than women are in this highearnings group in both sub-samples.

\section{[FIGURE 2]}

\section{Econometric methodology}

\subsection{A two-limit tobit model}

The observed dependent variable wage, denoted by $y$, is censored both from below (at the minimum threshold) and from above (at the maximum threshold). To account for repeated observations of the same firms at different times and for censoring, a twolimit random-effects tobit model (Rosett \& Nelson, 1975) is used, and specified as follows ${ }^{16}$ :

\footnotetext{
${ }^{16}$ Using ordinary least squares (OLS) regression on censored data is inappropriate. It results in biased and inconsistent estimates because the standard OLS assumption that the error term and the independent variables are uncorrelated is violated (Maddala, 1983). On the other hand, a fixed-effects model, in which unmeasured company- and/or time-specific influences are treated as constants rather than random
} 


$$
y_{i t}=\left\{\begin{array}{l}
\tau_{L} \text { if } y_{i t}^{*} \leq \tau_{L} \\
y_{i t}^{*}=x_{i t} \beta+\varepsilon_{i t} \text { if } \tau_{L} \leq \tau_{U} \\
\tau_{U} \text { if } y_{i t}^{*} \geq \tau_{U}
\end{array}\right\}
$$

where $y^{*}$ is the latent (index) variable, $\tau_{l}$ is the threshold of left-censoring and $\tau_{u}$ the threshold of right-censoring. Each company is denoted by $i$, and each monthly observation by $t$. A vector of explanatory variables is referred to as $x$, whereas $\beta$ is its associated vector of coefficients. The error is denoted by $\varepsilon_{i t}$. As the data are longitudinal, the model has a random-effects specification, which rests on the assumption that the distribution function of the errors is independent of the explanatory variables - i.e., the unobservable factors are not correlated with the explanatory variables (Arellano \& Honoré, 1999) ${ }^{17}$. In this model, the error is specified as the sum of transitory and permanent components as follows:

$$
\varepsilon_{i t}=v_{i t}+u_{i t}
$$

The transitory error component $\left(v_{i t}\right)$ captures unmeasured influences that vary over companies and time, while the permanent error component $\left(u_{i t}\right)$ captures unmeasured influences that vary over companies but persist through time. Both these components are assumed to be normally distributed with zero means and independent of each other, so that:

$$
\operatorname{Var}\left[\varepsilon_{i t}\right]=\sigma_{v}^{2}+\sigma_{u}^{2}
$$

where the parameter $\sigma_{u}$ is the standard deviation of the error part related to unobserved corporate heterogeneity. We control for unobserved firm-specific factors likely to affect the magnitude of the gender wage gap (Meng, 2004; Meng \& Meurs, 2004). For

variables, represents an alternative to variance components. This approach was not pursued because no consistent estimator exists for fixed-effects tobit models (Maddala, 1987).

${ }^{17}$ Likelihood-ratio tests for the pooled estimator against random-effects panel estimator indicate that the panel-level variance component is important and hence the pooled estimations are different from the panel estimations (see Tables $\mathrm{C}$ and 3). The reported coefficient of $\rho$, which is the panel-level variance component, provides a similar test. It represents the proportion of the total variance contributed by the panel-level variance component. As the tables show, the estimated value of $\rho$ in all regressions is significant. 
instance, low pay is usually linked to a wide range of factors, many of which are specific to the establishment- for example, low pay is frequent in single establishments and rarer in small establishments that are part of a larger organization (McNabb \& Whitfield, 2000)—and its competitive strategy (which is immeasurable). Also unobserved are the reasons why in certain companies females tend to get jobs with less training attached (and consequently have fewer opportunities to participate in on-the-job training to improve their productivity throughout their life). The standard deviation of $v_{i t}$ is also estimated, as is the case in all tobit models.

If $y^{*}$ can be assumed normally distributed, the tobit model will provide consistent and efficient estimates of parameters. Maximum likelihood estimation for the model involves dividing the observations into three sets. One contains uncensored observations, which maximum likelihood treats in the same way as the linear regression model. The other two contain left-censored and right-censored observations, respectively, for which the specific value of $y^{*}$ is not known. The probability of being left-censored is computed as:

$$
\operatorname{Pr}\left(y^{*} \leq \tau_{L} \mid x\right)=\Phi\left(\frac{\tau_{L}-x \beta}{\sigma}\right)
$$

and the probability of being right-censored as:

$$
\operatorname{Pr}\left(y^{*} \geq \tau_{U} \mid x\right)=1-\Phi\left(\frac{\tau_{U}-x \beta}{\sigma}\right)=\Phi\left(\frac{x \beta-\tau_{U}}{\sigma}\right)
$$

The likelihood function for all three sets of observations is then:

$$
\ln L=\sum_{\text {Lower }} \ln \Phi\left(\frac{\tau_{L}-x \beta}{\sigma}\right)+\sum_{\text {Uncensored }} \ln \frac{1}{\sigma} \phi\left(\frac{y-x \beta}{\sigma}\right)+\sum_{\text {Upper }} \ln \Phi\left(\frac{x \beta-\tau_{U}}{\sigma}\right)
$$

where $\phi$ and $\Phi$ are the probability density and the cumulative density functions, respectively, for the standard normal distribution, and $\sigma$ is the standard deviation of $\varepsilon$. Expected values for the latent outcome, $E\left(y^{*} \mid x\right)=x \beta$, are the primary focus of interest. 


\subsection{Oaxaca's approach to estimating wage discrimination}

As is standard in the empirical literature on between-group comparison of wages, we determine how much of any wage differential is due to differences in characteristics and how much is due to coefficient differences (i.e., differences in the returns to the characteristics). The standard interpretation of unexplained wage differentials (i.e. differences in wages that remain after having controlled for socioeconomic and demographic characteristics) is that there is discrimination (Blinder, 1973; Oaxaca, 1973). However, it must be stressed that the unexplained part of the gender wage gap may be due to factors other than discrimination - in this sense, since the data set includes repeated observations of the same firms at different times, this allows us to isolate a part of the unexplained wage gap which might be due to variable omissions. Part of the unexplained gap may be due to variables that are not included in the model. For instance, intensity of effort is a very important variable explaining wages, but this variable is absent from almost all data sets because it is very difficult to observe and measure. Thus caution should be exercised when interpreting the unexplained part of the gender wage gap as labour market discrimination: it can in principle be related to anything that is not associated with the observable characteristics.

Let $\ln \left(\bar{y}_{m}\right)$ and $\ln \left(\bar{y}_{f}\right)$ be the natural logs of mean male and female wages. If the log wage model of the previous section is estimated separately for male and female workers, then:

$$
\ln \left(\bar{y}_{m}\right)-\ln \left(\bar{y}_{f}\right)=\bar{X}_{m} \hat{\beta}_{m}-\bar{X}_{f} \hat{\beta}_{f}
$$

where $\overline{X_{m}}$ and $\overline{X_{f}}$ are vectors containing the means of the variables for male and female workers, respectively, and $\hat{\beta}_{m}$ and $\hat{\beta}_{f}$ are the estimated coefficients. Given this result, the log wage differential can be decomposed in two ways. Letting $\Delta \bar{X}^{\prime}=\bar{X}_{m}{ }^{\prime}-\bar{X}_{f}^{\prime}$, and $\Delta \hat{\beta}=\hat{\beta}_{m}-\hat{\beta}_{f},(7)$ can be written as:

$$
\ln \left(\bar{y}_{m}\right)-\ln \left(\bar{y}_{f}\right)=\Delta \bar{X}^{\prime} \beta_{m}+\bar{X}_{f} \Delta \beta
$$




$$
\ln \left(\bar{y}_{m}\right)-\ln \left(\bar{y}_{f}\right)=\Delta \bar{X}^{\prime} \beta_{f}+\bar{X}_{m} \Delta \beta
$$

The expression to the left of the equals sign in (8) (the "explained" part) is the part of the log wage differential due to different (average) characteristics when evaluated at men's returns. The expression on the right (the "unexplained" part) measures the differences in returns when evaluated at women's mean level of characteristics. This expression indicates the amount by which women's mean (logarithmic) wages would change for a given variable category if women were to receive men's estimated return to that characteristic (while retaining their own mean level of that characteristic). The alternative formulation in equation (9) reverses the weighting system, so that the differences in returns are weighted by working men's, rather than women's, mean level of characteristics. If in the absence of discrimination males and females received identical returns for the same characteristics — and differences in wages would therefore be due only to differences in pay-related characteristics - then the expression to the right of the equals sign in (8) and (9) can be interpreted as the part of the log wage differential due to discrimination. The question arises as to which of the two equations (8) or (9) to use in empirical work. If it is assumed that in the absence of discrimination the current male (female) wage structure would prevail, then the decomposition in equation 8 (9) would prevail. Given that these two equations might yield different decompositions (Neumark, 1988), we estimate gender wage differentials based on these two Oaxaca decompositions, as well as on an alternative decomposition where we use $\hat{\beta}=0.5 * \hat{\beta}_{m}+0.5 * \hat{\beta}_{f}$ as the non-discrimination wage structure (see Reimers, 1983).

\section{Results}

Table 3 shows the estimated results for the male and female tourism sub-samples, since it is essential to allow the intercept as well as the returns to each of the 
explanatory variables to vary between gender groups ${ }^{18}$. Most variables are

significantly different from zero at the $1 \%$ level and their estimated coefficients are consistent in general with a priori expectations ${ }^{19}$.

\section{[TABLE 3]}

As the table shows, younger workers (especially those under 30 years old) earn significantly lower monthly wages than workers above 45 . Other things equal, both men and women temporarily hired via temporary help agencies earn higher wages than their non-agency counterparts. Immigrants earn lower wages than their native counterparts, although this result is only significant for females (male immigrants do not earn significantly different wages from natives). Note also that job tenure is only a marginally significant variable for males: men earn lower wages when tenure is below six months, whereas the largest return to tenure is achieved for tenure between 1 and 2 years. No significant differences arise in the rest of the tenure categories (this may be attributed, as explained in Section 3 above, to the fact that in tourism there is generally little incentive/reward structure).

An important factor in pay is the qualification level required for the job. Qualification is highly positively correlated with wages, both for males and females (as expected). In addition, male employees in Camping sites and other commercial accommodation earn the highest wages, followed by the Hotel sub-industry. In contrast, women employed in Transportation, car hire, travel agencies, tour operators and tour guides earn the highest wages, while those employed in Recreational, cultural and sporting facilities earn the lowest wages.

\footnotetext{
${ }^{18}$ For the sake of comparison, wage equations for non-tourism industries were also estimated. These results are presented in Table $\mathrm{C}$ in the Appendix and are used to produce the wage decomposition shown in the lower part of Table 4.

${ }^{19}$ Skewness and kurtosis tests for the normality of the dependent variable (not shown) indicate that nonnormality must be accepted. This limitation is attenuated, however, by the fact that the estimations are done in large samples.
} 
With regard to firm size, the industrial structure in tourism usually has a dual character, with some examples of large organizations (e.g., resorts or airports) and many geographically-fragmented small concentrations (such as hotels, restaurants, visitor attraction centres or car rental offices). Large companies, because of the opportunities for advancement they offer, attract better, more productive workers (Evans \& Leighton, 1989), which creates pay differentials ${ }^{20}$. As expected, both men and women employed in firms with more than 100 employees earn higher wages than workers employed in smaller companies. In fact, the larger the size of the firm, the higher the monthly wages. Finally, the type of contract is a very significant variable in explaining wages. Both males and females holding interim contracts enjoy the highest wages, closely followed by individuals with open-ended contracts.

\section{[TABLE 4]}

The results in Table 3 show marked differences between men and women in the estimated coefficients for several variables. However, as Table 1 shows, each subsample differs in the average endowment of productivity characteristics and these differences may explain the observed wage gaps discussed in Section 4. Oaxaca (1973) offers a convenient decomposition of the observed wage gap into a portion attributable to differences in the average value of variables (the explained part) and a portion attributable to differences in the compensation for productivity characteristics (the unexplained part) — as explained in Section 5.2 above. Table 4 presents the wage decomposition results. Three representations of the estimated non-discriminatory wage structure were used. First, we use the estimated male wage structure as the nondiscriminatory norm for the Oaxaca-1 approach. The Oaxaca-2 approach assumes that there is no discrimination against female employees. Finally, the algorithm by Reimers (1983) is used. The estimated difference in the mean log wage between male and

\footnotetext{
${ }^{20}$ In addition, large firms are more likely to have adopted strong anti-discrimination policies in response to both public scrutiny and government sanction.
} 
female tourism employees is 0.065 ( 0.047 for non-tourism employees). Thus when account is taken of gender wage differences in the regressors, the average male earns $6.71 \%(4.81 \%)$ higher wages than the average female in (non-) tourism- these percentage figures are calculated as $\left(\mathrm{e}^{0.065}-1\right) * 100$ and $\left(\mathrm{e}^{0.047}-1\right) * 100$, respectively, since the exponent of a difference in logarithms is approximately equal to a percentage difference.

Focusing on the Reimers results, our calculation shows that differences in characteristics between men and women (the so-called endowment effect) account for $88 \%$ of the total wage gap in tourism (the magnitude of this effect is 0.058 ) - a far larger share than they are able to explain for the rest of the economy (where the endowment effect amounts to 0.006 , or $12.5 \%$ of the total wage gap). Thus in tourism only $12 \%$ of the wage gap is unexplained by these characteristics. In other words, women working in tourism would earn $12 \%$ more in the absence of differences in the wage structures $^{21}$. Thus this percentage may be interpreted either as gender wage discrimination or as the result of some un-measurable traits-henceforth, we label this component the "discrimination" component. The discrimination component for tourism industries in Spain found here is lower than that found for other countries. For instance, Delfim \& Varejao (2007) find that 55\% of the gender wage gap in the Portuguese tourism industry is due to discrimination.

The negative explained components associated with being an immigrant and agency hiring means that these characteristics favour the relative wage pattern of women. However, the cumulative contribution to the explained part $(0.058)$ of the gender wage gap emanating from these variables (as well as from age, job tenure and firm size) is rather small, and is totally offset by the rest of the components in Table 4 .

\footnotetext{
${ }^{21}$ The Oaxaca-2 decomposition for tourism workers is the only one which reveals that the unexplained component serves to reduce rather than widen the gap (see Table 4).
} 
In contrast, around $50 \%$ of the total wage gap in tourism industries is due to the type of contract held, followed by the level of qualification $(37.75 \%)$ and the sub-sector of employment (17.84\%). One can see why the explained wage differential due to differences in the type of contract is rather large. The male distribution (Table 1) is less concentrated on the Work experience and training contract category $(0.17 \%$ versus $0.38 \%$ ), and on the Per-task category ( $9.84 \%$ versus $11.78 \%$ ), but substantially more concentrated on the Open-ended category (60.61\% versus $49.49 \%)$. Since individuals hired under the first two types of contracts earn lower wages, and at the same time those holding Open-ended contracts earn higher wages (see Table 3), the resulting wage differential attributed to the type of contract is large. Analogously, and as mentioned in Section 4 above, men are more present than women in tourism jobs requiring relatively high qualification levels (where the highest wages are earned, according to the estimation results in Table 3). Thus considerable segregation exists across occupational levels within the industry. As regards the proportion of the gap due to differences in the sub-sector of employment, men have comparatively more weight in Restaurants, where wages are higher (Table 1). Thus although females are more likely to be employed in Hotels and Transport, car hire, travel agencies, tour operators \& tour guides - where wages are higher than in the reference category (i.e., Recreational, cultural and sporting facilities) - either their relative presence in these sub-sectors or their market rewards are not enough to countervail the wage differential favourable to males. In essence, the large share of women in occupations with lower rewards has important adverse effects on women's pay. If these are unconstrained choices, then the explained portion of the gap stands, but it is rather likely to include some degree of industrial, qualification or contractual "discrimination".

Our results provide evidence of a significant disparity in wages to the detriment of women in non-tourism industries that cannot be attributed to differences in observable variables: among non-tourism workers, the component attributed to unobserved 
characteristics $(87.49 \%)$ is substantially larger than the one for tourism workers. This figure is slightly larger than the one found in prior studies on discrimination studiese.g., Weichselbaumer \& Winter-Ebmer (2003) find that the discrimination component tends to amount to roughly $60 \%$ - but lies inside the wide range of variation in reported wage gap estimates in previous literature — Stanley \& Jarrell (1998) find variations from $-2.7 \%$ to $91 \%$ with a mean of $31.8 \%$. Thus with the data available most of the overall gender wage gap among non-tourism workers cannot be explained by the differences in productivity endowments.

\section{Conclusion and implications}

In this paper we analyze the gender wage gap of full-time employees in the Spanish tourism industry. Because very scarce matching evidence is available for other tourism labour markets, we also compare the extent of gender pay differences in the Spanish tourism industry with what occurs in the rest of the economy. To do this, we use a large employer-employee data set from the Social Security records that allows us to control for unobserved heterogeneity at the firm level, and specify monthly wages as a function of socio-economic, demographic and labour market characteristics.

We find that in tourism male workers earn on average $6.7 \%$ higher monthly wages than their socially comparable female counterparts, while among non-tourism workers the predicted gender wage gap is slightly narrower (4.8\%). In addition, the wage gap in tourism is due to segregation as regards the type of contract held, the qualification required for the job and the sub-sector of employment: these three variables are especially penalizing for women. An intriguing question is to ask about the reasons for the segregation, since it may be due either to choice or to entry barriers. In any case, our results suggest that in Spain the gender wage gap is a matter of employment opportunities and firms' decision to offer equal pay for equal work or not.

One of the main questions is how much of the wage gap can be attributed to discrimination. Our findings provide evidence that the disparity in wages suffered by 
women cannot be attributed fully to differences in observable characteristics. Despite taking into account a wide variety of explanatory variables, in tourism the unexplained component accounts for approximately $12 \%$ of the overall gender wage differential. This unobserved component is substantially lower that the one observed for nontourism employees $(87.49 \%)$. Our explanation for this difference is that men have been incumbents in some of the non-tourism industries for many years. Thus initiatives in which companies in these industries recruit, hire, promote and remunerate women on an equal standing with men cannot transform the structure of earnings overnight.

Our results also suggest that the minimum wage legislation in Spain provides effective protection to female low-wage earners in tourism industries. Although minimum wages are set for all occupations and economic sectors, they have a particularly strong impact in low-wage industries where a larger share of workers is covered by the legislation. In Spain, indeed, around $81.3 \%$ of minimum wage recipients belong to the service sector (Gutiérrez \& Schwartz, 1997). As a result, it is logical to expect there to be less room for pay "discrimination" among low-wage workers in low-wage industries (such as tourism). This is exactly what our empirical findings show. Our results also imply that minimum wage legislation may offer stronger protection to women working in the tourism industry than equal pay provisions, which require the submission of complaints that do not impose actions on employers to ensure equal pay. As a result, these provisions may be easily undone by employers.

Finally, we cannot offer definitive arguments on these points with the data available, since we imputed the presence of bias or discrimination from evidence of its effects after controlling for observable variables in the data. Certainly, more precise data are needed to study wage discrimination — e.g., covert attitudes and policies (such as hiring and promotion practices, apart from pay practices). Thus in the current work we do not aim to offer, by any means, scientific evidence of bias. In future research we plan to find theoretical explanations for these results. This will involve making 
predictions about the distribution of the wage gap based on different theories of discrimination. In turn, this could help us to formulate hypotheses that allow us to test which of these different theories is correct. 


\section{References}

Amuedo-Dorantes, C. \& S. De la Rica (2006). The Role of Segregation and Pay Structure on the Gender Wage Gap: Evidence from Matched Employer-Employee Data for Spain. Contributions to Economic Analysis \& Policy, 5 (1), article 10.

Arellano, M. \& B. Honoré (1999). Panel Data Models: Some Recent Developments. In Heckman, J.J. \& Leamer, E. (Eds.). Handbook of Econometrics, volume 5 (pp. 32293296). North-Holland: Amsterdam.

Becker, G. (1962). Investment in human capital: a theoretical analysis. Journal of Political Economy, 70, 9-49.

Blinder, A.S. (1973). Wage Discrimination: Reduced Form and Structural Elements. Journal of Human Resources, 8(4), 436-455.

Cain, Glen C. (1986). The economic analysis of labor market discrimination: a survey. In O. Ashenfelter \& R. Layard (Eds.), Handbook of Labor Economics, volume 1, North Holland: Amsterdam (pp. 693-785)

Caparros Ruiz, A., Navarro Gómez, María L., \& M. F. Rueda Narváez (2004). Gender wage gaps and job mobility in Spain. International Journal of Manpower, 25, 3/4, 264-278.

Castro, A., González, P, Osorio, A. \& A. Meixide (1999). The Portuguese and Spanish labour markets: so alike yet so different? In Christiansen, J., Koistinen, P. \& Kovalainen, A.(eds.). Working Europe: Reshaping European Employment Systems, Aldershot: Ashgate.

Cooper, C., Fletcher, J., Gilbert, D. \& S. Wanhill (1993). Tourism: Principles and Practice. London: Pitman.

Corcoran, M. \& G. Duncan (1979). Work History, Labor Force Attachment and Earnings Difference Between the Sexes. Journal of Human Resources, 14, 3-20.

Cox, D. (1984). Panel Estimates of the Effects of Career Interruptions on the Earnings of Women. Economic Inquiry, 22, July, 386-403.

De la Rica, S. \& A. Ugidos (1995). ¿Son las diferencias en capital humano determinantes de las diferencias salariales observadas entre hombres y mujeres? Investigaciones Económicas, 19 (3), 395-414.

De la Rica, S., J.J. Dolado \& V. Llorens (2008). Ceilings or floors? Gender wage gaps by education in Spain. Journal of Population Economics, 21, 751-776.

Delfim Santos, L. \& J. Varejao (2007). Employment, pay and discrimination in the tourism industry. Tourism Economics, 13(2), 225-240.

Diamond, J. (1977). Tourism's role in economic development: The case re-examined. Economic Development and Cultural Change, 25 (3), 539-553.

Doherty, L. \& L. Stead (1998). The gap between male and female pay: what does the case of hotel and catering tell us?. The Service Industries Journal, 18 (4), 126-144. 
Dolado, J.J., Felgueroso, F. \& J.F. Jimeno (2004). Where Do Women Work?: Analysis Patterns of Occupational Segregation by Gender. Annales d'Economie et de Statistique, 0 (71-72), 293-315.

Enloc, C. (1989). Bananas, Beaches and Bases: Making Feminist Sense of International Politics. Pandora, London.

Evans, D. \& L. Leighton (1989). Why do small firms pay less. Journal of Human Resources, 24, 299-318.

Gardeazábal J. \& A. Ugidos (2005). Gender wage discrimination at quantiles. Journal of Population Economics, 18:165-179

García J., Hernández, Pedro J. \& A. López-Nicolás (2001). How wide is the gap? an investigation of gender wage differences using quantile regression. Empirical Economics, 26:149-168.

Groshen, E. L. (1991). The structure of the female/male wage differential: Is it who you are, what you do, or where you work?". Journal of Human Resources, 26, 457473.

Gutiérrez Hevia, I. \&. Schwartz, P. (1997). Minimum wages in Spain. Institute of Economic Affairs, 15-21.

Hernández, Pedro J. (1995). Análisis empírico de la discriminación salarial de la mujer en España. Investigaciones Económicas, XIX, 2, 195-215.

Hernández, Pedro J. (1996). Segregación ocupacional de la mujer y discriminación salarial. Revista de Economía Aplicada, 11 (6), 57-80.

Joshi, H. (1984). Women's participation in paid work. Further Analysis of the Women and Employment Survey. Department of Employment Research Paper, 45, London: Department of Employment

Kinnaird, V., Kothari, U. \& D. Hall (1994). Tourism: Gender perspectives. In V. Kinnaird \& D. Hall (Eds.), Tourism: A Gender Analysis. New York: Wiley.

Kinnaird, V. \& D. Hall (1996). Understanding tourism processes: a gender-aware framework. Tourism Management, 17, 95-102.

Maddala, G.S. (1983). Limited-Dependent and Qualitative Variables in Econometrics. Cambridge: Cambridge University Press.

Maddala, G.S. (1987). Limited Dependent Variable Models Using Panel Data. Journal of Human Resources, Summer, 307-338.

Meng X. (2004)."Gender earnings gap: the role of firm specific effects. Labour Economics, 11, 555-573.

Meng X. \& D. Meurs (2004). The gender earnings gap: Effects of institutions and firms. A comparative study of French and Australian private firms. Oxford Economic Papers, 56, 189-208. 
Mincer, J. \& B. Jovanovic (1981). Labor mobility and wages. In S. Rosen (Ed.), Studies in Labor Markets (pp. 21-64). Chicago: University of Chicago Press.

Mincer, J. \& H. Ofek (1982). Interrupted Work Careers: Depreciation and Restoration of Human Capital. Journal of Human Resources, 17, Winter, 3-24.

Mincer, J. \& S. Polachek (1974). Family Investments in Human Capital: Earnings of Women. Journal of Political Economy, 82, 2 (2), S76-S108.

Murgatroyd, L. (1982). Gender and occupational stratification. Sociological Review, 30, 572-601.

Oaxaca, R. L. (1973). Male-Female Differentials in Urban Labor Markets. International Economic Review, vol. 14(3), 693-709.

Reimers, C. (1983). Labor Market Discrimination Against Hispanic and Black Men. The Review of Economics and Statistics, 65 (4), 570-79.

Richter, L.K. (1995). Gender and race: neglected variables in tourism research. In R. Butler \& D. Pearce (Eds.), Change in Tourism: People, Places and Proceses. London: Routledge.

Riley, M., A. Ladkin \& E. Szivas (2002). Tourism employment: Analysis and Planning. Clevedon: Channel View Publications.

Riley, M., \& E. Szivas (2003). Pay determination: A Socioeconomic Framework. Annals of Tourism Research, 30 (2), 446-464.

Rosen, S., 1972. Learning and Experience in the Labor Market. Journal of Human Resources 7, pp. 326-342.

Rosett, R. N. \& Nelson, F. D. (1975). Estimation of the Two-limit Probit Regression Model. Econometrica, 43, 141-146.

Royle, T. (1999). The reluctant bargainers? McDonald's unions and pay determination in Germany and the UK. Industrial Relations Journal, 30 (2), 135-150.

Rubery, J. \& Fagan, C. (1994). Occupational segregation and the prospects for gender pay equity. Journal of Management Studies, 32 (5), 637-654.

Sinclair, M. T. (1997). Issues and theories of gender and work in tourism. In Sinclair, M. T. (ed.). Gender, Work and Tourism. London: Routledge.

Sorensen, E. (1989). Measuring pay disparity between typically female occupations and other jobs: A bivariate selectivity approach. Industrial and Labor Relations Review, 42, 624-639.

Sparrow, R.T. \& K. M. Iverson (1999). Cracks in the glass ceiling? An empirical study of gender differences in income in the hospitality industry. Journal of Hospitality and Tourism Research, 23 (1), 4-20.

Stanley, T.D. \& S. B. Jarrell (1998). Gender wage discrimination bias? A metaregression analysis, The Journal of Human Resources, 23, 947-973. 
Threlfall, M. (2000). Comparing unemployment in the UK and European Union: a gender and working time analysis. Policy and Politics, 28, 309-329.

Weichselbaumer, D. \& Winter-Ebmer, R. (2005). A meta-analysis of the international gender wage gap. Journal of Economic Surveys, 19 (3), 479-511.

Wilkinson, P. \& Pratiwi, W. (1995). Gender and tourism in an Indonesian village. Annals of Tourism Research, 22 (2), 283-299. 


\section{APPENDIX}

TABLE A

Aggregation of Social Security Contribution Groups into skills levels

Skills Level Description of corresponding Social Security Contribution Groups

Qual. 1
$\begin{aligned} & 1 \text { - engineers and graduates - ingenieros y licenciados } \\ & 2 \text { - technical engineers and other skilled workers- ingenieros técnicos, } \\ & \text { peritos y ayudantes titulados }\end{aligned}$

Qual. 2 - chief and departmental heads - jefes administrativos y de taller

4 - other semi-skilled workers- ayudantes no titulados

\begin{tabular}{ll}
\hline Qual. 3 & 5 -skilled clerks - oficiales administrativos \\
& 6 - auxiliary workers- subalternos \\
\hline Qual. 4 & 7 -semi-skilled clerks- auxiliares administrativos \\
& 8 -skilled labourers- oficiales de primera y segunda \\
\hline Qual. 5 & 9 - semi-skilled labourers - oficiales de tercera y especialistas \\
& 10 - unskilled labourers- peones
\end{tabular}

Note: These groups are proxies for workers' skills level, because these categories are a mix of occupation and educational level required for jobs.

TABLE B

Description of Work Contract Denominations Used in the Analysis

\section{Work Contract Name Description}

Work-Experience

(Practice) Contract

(Contrato de prácticas)

Training Contract

(Contrato de formación)

Interim Contract

(Contrato de interinidad)

Per-task Contract

(Contrato de obra o servicio)

Casual Contract

(Contrato eventual por

circunstancias de la

producción)
The purpose of this contract is to enable persons who have completed secondary, vocational training or university education to gain work experience according to their educational level

This contract is related to the provision of theoretical and practical knowledge required to perform a skilled job. This contract replaced the old apprenticeship contract in 1997

This temporary contract is related to interim situations in the firm

This contract was introduced for firms' temporary needs related to specific work or services of unknown duration (but presumably not permanent)

This contract is related to unusual or seasonal circumstances of the goods markets and excess of work in the firm 
TABLE C. Results of random-effects tobit models, by gender. Non-tourism subsample

\begin{tabular}{|c|c|c|c|c|c|c|}
\hline & \multicolumn{3}{|c|}{ MEN } & \multicolumn{3}{|c|}{ WOMEN } \\
\hline & Coeff. & Std. Err. & Sig. & Coeff. & Std. Err. & Sig. \\
\hline Constant & 7.028 & 0.007 & $* * *$ & 7.086 & 0.016 & $* * *$ \\
\hline \multicolumn{7}{|l|}{ Age: } \\
\hline $16-29$ & -0.117 & 0.003 & $* * *$ & -0.059 & 0.005 & $* * *$ \\
\hline $30-45$ & -0.040 & 0.003 & $* * *$ & -0.004 & 0.005 & \\
\hline $46-65$ & - & - & - & - & - & - \\
\hline Temporary Help Agency & 0.157 & 0.011 & $* * *$ & 0.164 & 0.011 & $* * *$ \\
\hline Immigrant & -0.002 & 0.006 & & 0.025 & 0.012 & $* *$ \\
\hline \multicolumn{7}{|l|}{ Job tenure (months): } \\
\hline$\leq 6$ & 0.034 & 0.003 & $* * *$ & 0.026 & 0.005 & $* * *$ \\
\hline$>6 \& \leq 12$ & 0.010 & 0.004 & $* * *$ & 0.006 & 0.005 & \\
\hline$>12 \& \leq 24$ & 0.008 & 0.003 & $* *$ & 0.006 & 0.005 & \\
\hline$>24$ & - & - & - & - & - & - \\
\hline \multicolumn{7}{|l|}{ Sub-sector of employment in non-tourism: } \\
\hline Construction & - & - & - & - & - & - \\
\hline Agriculture & -0.084 & 0.025 & $* * *$ & 0.090 & 0.031 & $* * *$ \\
\hline Mining \& industry & -0.006 & 0.006 & & -0.025 & 0.015 & $*$ \\
\hline Retailing & -0.059 & 0.006 & $* * *$ & -0.079 & 0.014 & $* * *$ \\
\hline Transport \& Telecommunications & -0.096 & 0.007 & $* * *$ & 0.054 & 0.018 & $* * *$ \\
\hline Finance, Estate agencies, R\&D \& Computing & -0.023 & 0.007 & $* * *$ & -0.040 & 0.015 & $* * *$ \\
\hline Public administration & -0.044 & 0.017 & $* *$ & -0.071 & 0.021 & $* * *$ \\
\hline Teaching & -0.213 & 0.015 & $* * *$ & -0.140 & 0.020 & $* * *$ \\
\hline Health \& Sanitation & -0.046 & 0.016 & $* * *$ & -0.164 & 0.015 & $* * *$ \\
\hline Associations \& Personnel services & -0.196 & 0.012 & $* * *$ & -0.258 & 0.016 & $* * *$ \\
\hline Domestic service & -0.223 & 0.030 & $* * *$ & -0.196 & 0.055 & $* * *$ \\
\hline \multicolumn{7}{|l|}{ Firm size: } \\
\hline$\leq 25$ & -0.072 & 0.004 & $* * *$ & -0.260 & 0.005 & $* * *$ \\
\hline$>25 \& \leq 50$ & -0.040 & 0.005 & $* * *$ & -0.176 & 0.007 & $* * *$ \\
\hline$>50 \& \leq 100$ & -0.003 & 0.005 & & -0.120 & 0.006 & $* * *$ \\
\hline$>100$ & - & - & - & - & - & - \\
\hline \multicolumn{7}{|l|}{ Type of contract: } \\
\hline Open-ended & - & - & - & - & - & - \\
\hline Per-task & -0.084 & 0.004 & $* * *$ & -0.062 & 0.005 & $* * *$ \\
\hline Casual & -0.113 & 0.004 & $* * *$ & -0.077 & 0.005 & $* * *$ \\
\hline Work experience \& training & -0.299 & 0.014 & $* * *$ & -0.241 & 0.015 & $* * *$ \\
\hline Interim & -0.323 & 0.082 & $* * *$ & -0.774 & 0.205 & $* * *$ \\
\hline Other temporary & -0.140 & 0.010 & $* * *$ & -0.060 & 0.008 & $* * *$ \\
\hline \multicolumn{7}{|l|}{ Qualification group: } \\
\hline Qual. 1 & 0.517 & 0.006 & $* * *$ & 0.491 & 0.007 & $* * *$ \\
\hline Qual. 2 & 0.370 & 0.005 & $* * *$ & 0.370 & 0.008 & $* * *$ \\
\hline Qual. 3 & 0.172 & 0.005 & $* * *$ & 0.201 & 0.006 & $* * *$ \\
\hline Qual. 4 & 0.091 & 0.003 & $* * *$ & 0.095 & 0.005 & $* * *$ \\
\hline Qual. 5 & - & - & - & - & - & - \\
\hline$\sigma_{u}$ & 0.204 & 0.002 & $* * *$ & 0.210 & 0.002 & $* * *$ \\
\hline$\sigma_{v}$ & 0.346 & 0.001 & $* * *$ & 0.360 & 0.001 & $* * *$ \\
\hline$\rho$ & 0.258 & 0.003 & $* * *$ & 0.254 & 0.004 & $* * *$ \\
\hline $\begin{array}{l}\text { Log likelihood } \\
\mathrm{n} \text { observations } \\
\mathrm{n} \text { firms } \\
\text { Likelihood ratio test }^{\mathrm{a}}\end{array}$ & \multicolumn{3}{|c|}{$\begin{array}{c}-62057.667 \\
130,850 \\
6,521 \\
\chi^{2}(1)=3.7 * 10^{4} \\
\text { Prob } \geq \chi^{2}=0.000\end{array}$} & \multicolumn{3}{|c|}{$\begin{array}{c}-37520.626 \\
77,098 \\
5,007 \\
\chi^{2}(1)=2.1 * 10^{4} \\
\text { Prob } \geq \chi^{2}=0.000\end{array}$} \\
\hline
\end{tabular}

\footnotetext{
${ }^{a}$ Denotes likelihood-ratio test, which provides a test for pooled (tobit) estimator against random-effects
} panel estimator; *** significant at $1 \%$; ** significant at $5 \%$; * significant at $10 \%$. Regressions also control for years (1998-2003) and regions 
FIGURE 1. Empirical distribution of monthly wages for tourism temporary workers, by gender

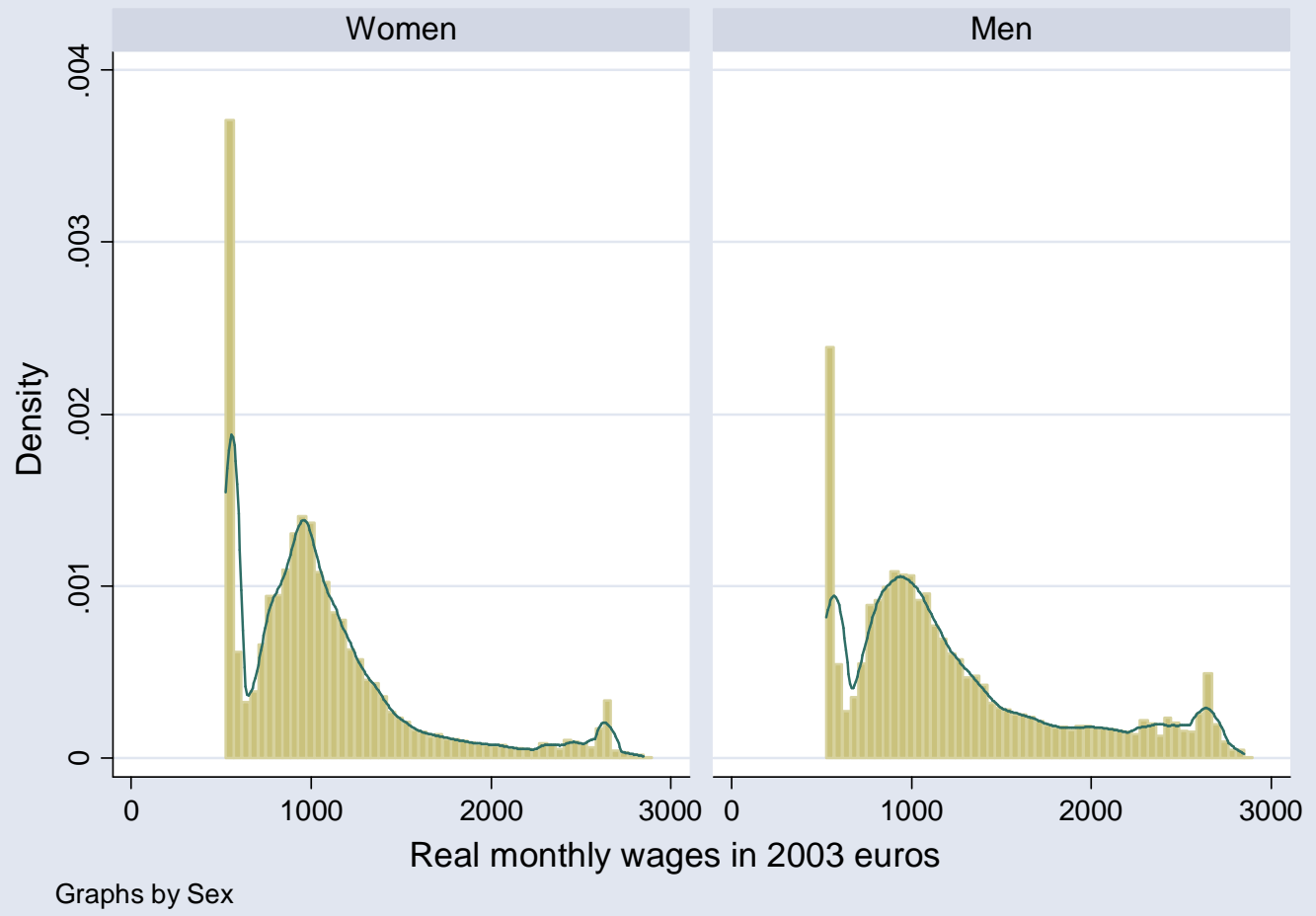

FIGURE 2. Empirical distribution of monthly wages for non-tourism temporary workers, by gender

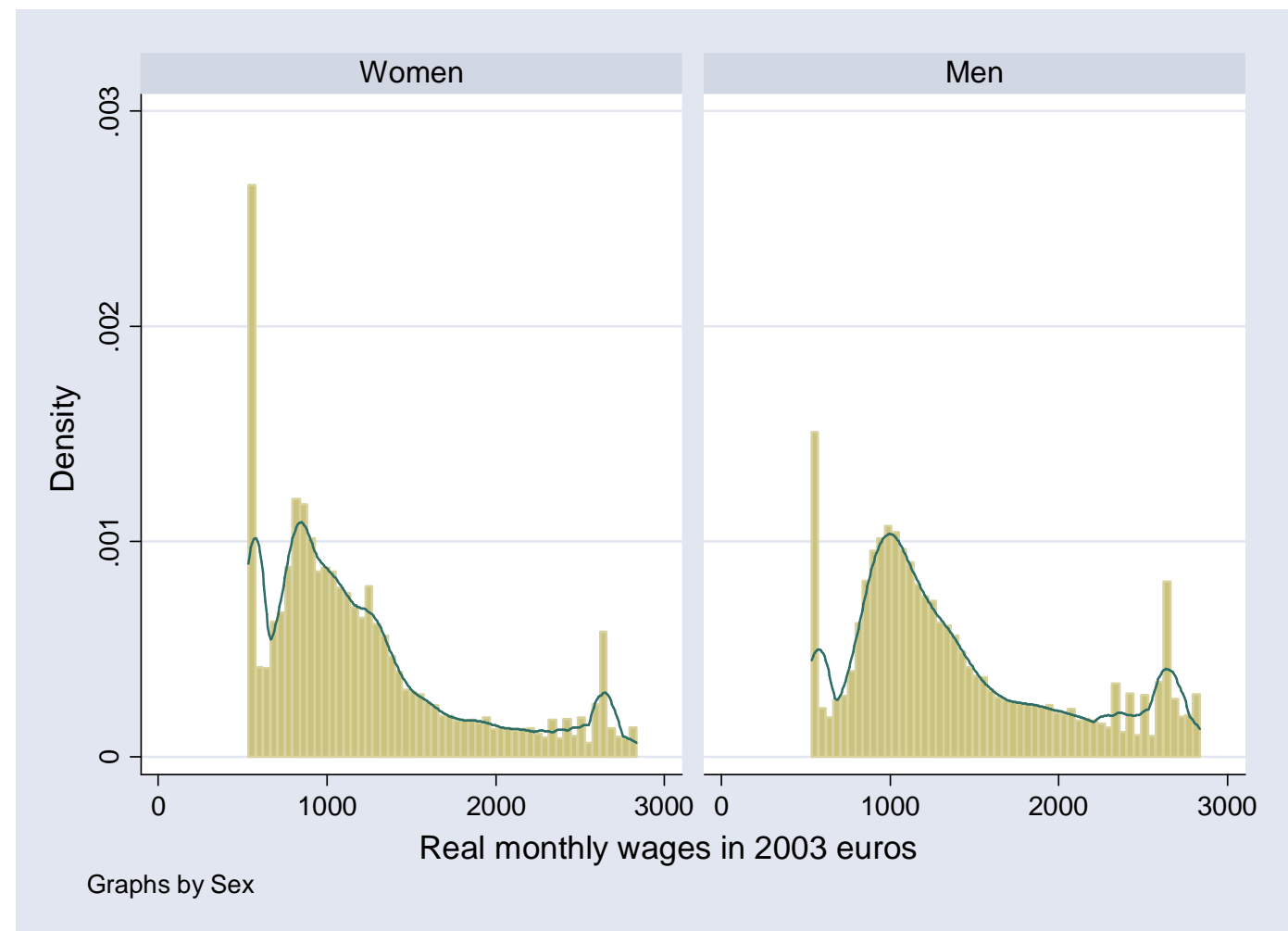


Table 1. Distribution of sub-samples and mean wages, by sex. Tourism sub-sample

\begin{tabular}{|c|c|c|c|c|c|c|c|c|c|}
\hline & & Obs. $(\%)$ & $\begin{array}{l}\text { MEN } \\
\text { Mean }\end{array}$ & Std. Dev. & Obs. (\%) & $\begin{array}{c}\text { WOMEN } \\
\text { Mean }\end{array}$ & Std. Dev. & Raw gap ${ }^{a}$ & $\begin{array}{c}\mathrm{F} / \mathrm{M} \text { ratio } \\
(\%)\end{array}$ \\
\hline Monthly real earnings & & - & 1252.005 & 602.967 & - & 1067.096 & 491.438 & $184.909 * * *$ & 85.231 \\
\hline Temporary Help Agency: & $\begin{array}{r}\text { No } \\
\text { Yes }\end{array}$ & $\begin{array}{c}97.291 \\
2.709\end{array}$ & $\begin{array}{l}1244.232 \\
1531.222\end{array}$ & $\begin{array}{c}602.129 \\
565.5244\end{array}$ & $\begin{array}{c}96.431 \\
3.569\end{array}$ & $\begin{array}{c}1055.36 \\
1384.155\end{array}$ & $\begin{array}{c}483.7082 \\
583.966\end{array}$ & $\begin{array}{l}188.872 * * * \\
147.067 * * *\end{array}$ & $\begin{array}{l}84.820 \\
90.395 \\
\end{array}$ \\
\hline Immigrant & $\begin{array}{r}\text { No } \\
\text { Yes } \\
\end{array}$ & $\begin{array}{c}91.879 \\
8.121 \\
\end{array}$ & $\begin{array}{l}1263.759 \\
1119.015 \\
\end{array}$ & $\begin{array}{l}607.2101 \\
535.0293 \\
\end{array}$ & $\begin{array}{c}92.369 \\
7.631 \\
\end{array}$ & $\begin{array}{c}1069.14 \\
1042.357 \\
\end{array}$ & $\begin{array}{c}489.357 \\
515.3609 \\
\end{array}$ & $\begin{array}{c}194.619 * * * \\
76.658 * * *\end{array}$ & $\begin{array}{l}84.600 \\
93.150 \\
\end{array}$ \\
\hline Qualification group ${ }^{c}$ : & $\begin{array}{r}\text { Qual. 1 } \\
\text { Qual. 2 } \\
\text { Qual. } 3 \\
\text { Qual. } 4 \\
\text { Qual. 5 } \\
\end{array}$ & $\begin{array}{c}2.762 \\
8.218 \\
8.773 \\
49.982 \\
30.265 \\
\end{array}$ & $\begin{array}{l}1907.211 \\
1568.234 \\
1296.263 \\
1306.401 \\
1003.686 \\
\end{array}$ & $\begin{array}{l}757.8424 \\
633.7099 \\
561.1497 \\
608.9996 \\
450.1717 \\
\end{array}$ & $\begin{array}{c}1.612 \\
4.475 \\
10.764 \\
35.269 \\
47.880 \\
\end{array}$ & $\begin{array}{l}1854.576 \\
1358.067 \\
1240.675 \\
1104.367 \\
946.9167 \\
\end{array}$ & $\begin{array}{l}735.4805 \\
584.1971 \\
528.4285 \\
461.4706 \\
428.5684 \\
\end{array}$ & $\begin{array}{c}52.635 * * \\
210.167 * * * \\
55.588 * * * \\
202.034 * * * \\
56.7693 * * * \\
\end{array}$ & $\begin{array}{l}97.240 \\
86.598 \\
95.712 \\
84.535 \\
94.344 \\
\end{array}$ \\
\hline Job tenure (months): & $\begin{array}{r}\leq 6 \\
>6 \& \leq 12 \\
>12 \& \leq 24 \\
>24 \& \leq 36 \\
\end{array}$ & $\begin{array}{l}43.003 \\
20.083 \\
22.497 \\
14.416 \\
\end{array}$ & $\begin{array}{l}1203.719 \\
1272.213 \\
1314.338 \\
1270.618 \\
\end{array}$ & $\begin{array}{l}594.8973 \\
608.0456 \\
620.1432 \\
580.6839 \\
\end{array}$ & $\begin{array}{l}49.037 \\
19.956 \\
19.248 \\
11.759 \\
\end{array}$ & $\begin{array}{l}1058.946 \\
1073.407 \\
1079.326 \\
1070.355 \\
\end{array}$ & $\begin{array}{l}508.7036 \\
493.4824 \\
464.4748 \\
455.7938 \\
\end{array}$ & $\begin{array}{l}144.773 * * * \\
198.806 * * * \\
235.012 * * * \\
200.263 * * * \\
\end{array}$ & $\begin{array}{l}87.973 \\
84.373 \\
82.119 \\
84.239 \\
\end{array}$ \\
\hline Firm size (number of employees): & $\begin{array}{r}\leq 25 \\
>25 \& \leq 50 \\
>50 \& \leq 100 \\
>100\end{array}$ & $\begin{array}{c}53.825 \\
18.389 \\
8.475 \\
19.310 \\
\end{array}$ & $\begin{array}{c}1042.77 \\
1254.737 \\
1259.884 \\
1829.164 \\
\end{array}$ & $\begin{array}{l}471.5143 \\
566.2174 \\
566.2303 \\
601.5857 \\
\end{array}$ & $\begin{array}{l}53.699 \\
17.001 \\
11.594 \\
17.706 \\
\end{array}$ & $\begin{array}{l}988.2396 \\
1165.243 \\
1070.726 \\
1209.637 \\
\end{array}$ & $\begin{array}{c}444.8667 \\
529.4422 \\
492.4561 \\
536.161 \\
\end{array}$ & $\begin{array}{c}54.5304 * * * \\
89.494 * * * \\
189.158 * * * \\
619.527 * * * \\
\end{array}$ & $\begin{array}{l}94.771 \\
92.868 \\
84.986 \\
66.131 \\
\end{array}$ \\
\hline Type of contract: & $\begin{array}{r}\text { Open-ended } \\
\text { Per-task } \\
\text { Casual } \\
\text { Work experience \& Training } \\
\text { Interim } \\
\text { Other temporary }\end{array}$ & $\begin{array}{c}60.611 \\
9.836 \\
22.193 \\
0.175 \\
1.735 \\
5.449\end{array}$ & $\begin{array}{l}1344.195 \\
1178.285 \\
1109.155 \\
1031.695 \\
1495.931\end{array}$ & $\begin{array}{l}612.7993 \\
547.0284 \\
538.4497 \\
467.1652 \\
617.1846 \\
541.1471\end{array}$ & $\begin{array}{c}49.491 \\
11.778 \\
25.707 \\
0.385 \\
2.225 \\
\\
10.412\end{array}$ & $\begin{array}{c}1128.095 \\
1060.31 \\
1078.919 \\
1054.225 \\
1267.978 \\
713.1886\end{array}$ & $\begin{array}{c}462.416 \\
471.7333 \\
524.7353 \\
481.0072 \\
586.142 \\
371.1715\end{array}$ & $\begin{array}{c}216.1 * * * \\
117.975 * * * \\
30.236 * * * \\
-22.53 \\
227.953 * * * \\
157.6455 * * *\end{array}$ & $\begin{array}{c}83.923 \\
89.988 \\
97.274 \\
102.184 \\
84.762 \\
81.897\end{array}$ \\
\hline Sub-sector in tourism: & $\begin{array}{r}\text { Hotels } \\
\text { Camping sites \& other commercial } \\
\text { accommodation } \\
\text { Restaurants } \\
\text { Transport, Car hire, Travel agencies, } \\
\text { tour operators \& tour guides } \\
\text { Recreational, cultural \& sporting } \\
\text { facilities }\end{array}$ & $\begin{array}{l}43.625 \\
23.976 \\
24.487 \\
3.245 \\
4.668\end{array}$ & $\begin{array}{l}1187.421 \\
1013.054 \\
1583.987 \\
1494.597 \\
1172.768\end{array}$ & $\begin{array}{l}531.3452 \\
436.946 \\
710.359 \\
617.9301 \\
547.4716\end{array}$ & $\begin{array}{c}49.891 \\
33.667 \\
6.225 \\
5.224 \\
4.994\end{array}$ & $\begin{array}{l}1078.817 \\
947.3209 \\
1455.229 \\
1251.704 \\
1080.541\end{array}$ & $\begin{array}{l}489.0059 \\
398.0225 \\
626.3566 \\
490.6467 \\
562.9261\end{array}$ & $\begin{array}{l}108.604 * * * \\
65.7331 * * * \\
128.758 * * * \\
242.893 * * * \\
92.227 * * *\end{array}$ & $\begin{array}{l}90.854 \\
93.511 \\
91.871 \\
83.749 \\
92.136\end{array}$ \\
\hline
\end{tabular}

a "Raw gap" is difference in mean monthly wages between sexes; " "F/M ratio" is mean female monthly wages/mean male monthly wages; ${ }^{\mathrm{c}}$ See Table A in Appendix for categories inside each qualification level. *** significant at $1 \%$; ** significant at $5 \%$; ${ }^{*}$ significant at $10 \%$ 
Table 2. Distribution of sub-samples and mean wages, by sex. Non-tourism sub-sample

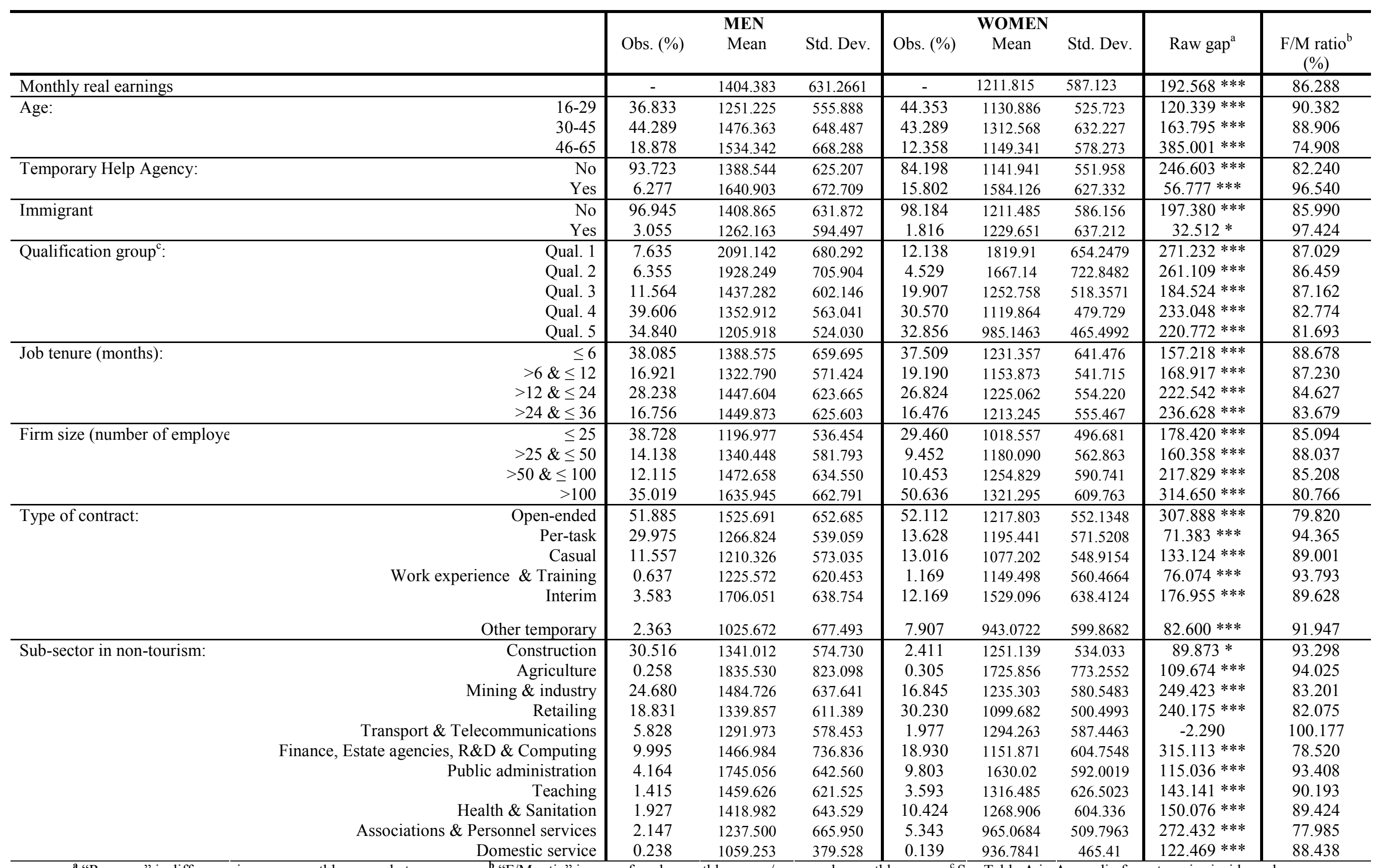

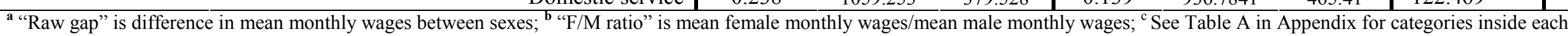
qualification level. $* * *$ significant at $1 \%$; ** significant at $5 \%$; $*$ significant at $10 \%$ 
Table 3. Results of random-effects tobit models, by gender. Tourism sub-sample

\begin{tabular}{|c|c|c|c|c|c|c|}
\hline & \multicolumn{3}{|c|}{ MEN } & \multicolumn{3}{|c|}{ WOMEN } \\
\hline & Coeff. & Std. Err. & Sig. & Coeff. & Std. Err. & Sig. \\
\hline Constant & 6.926 & 0.018 & $* * *$ & 6.734 & 0.017 & $* * *$ \\
\hline \multicolumn{7}{|l|}{ Age: } \\
\hline $16-29$ & -0.092 & 0.005 & $* * *$ & -0.041 & 0.005 & $* * *$ \\
\hline $30-45$ & -0.042 & 0.004 & $* * *$ & -0.023 & 0.005 & $* * *$ \\
\hline $46-65$ & - & - & - & - & - & - \\
\hline Temporary Help Agency & 0.263 & 0.015 & $* * *$ & 0.025 & 0.015 & $*$ \\
\hline Immigrant & -0.007 & 0.005 & & -0.019 & 0.007 & $* * *$ \\
\hline \multicolumn{7}{|l|}{ Job tenure (months): } \\
\hline$\leq 6$ & -0.009 & 0.005 & $*$ & -0.005 & 0.006 & \\
\hline$>6 \& \leq 12$ & 0.000 & 0.005 & & 0.006 & 0.006 & \\
\hline$>12 \& \leq 24$ & 0.010 & 0.005 & $* *$ & 0.008 & 0.006 & \\
\hline$>24$ & - & - & - & - & - & - \\
\hline \multicolumn{7}{|l|}{ Sub-sector of employment in tourism: } \\
\hline Hotels & 0.095 & 0.008 & $* * *$ & 0.185 & 0.009 & $* * *$ \\
\hline Camping sites \& other commercial accommodation & 0.159 & 0.008 & $* * *$ & 0.101 & 0.009 & $* * *$ \\
\hline Restaurants & 0.022 & 0.008 & $* * *$ & 0.125 & 0.011 & $* * *$ \\
\hline \multirow{2}{*}{\multicolumn{7}{|c|}{$\begin{array}{r}\text { Transport, Car hire, Travel agencies, tour operators } \\
\& \text { tour guides }\end{array}$}} \\
\hline & 0.022 & 0.007 & $* * *$ & 0.299 & 0.010 & $* * *$ \\
\hline Recreational, cultural \& sporting facilities & - & - & - & - & - & - \\
\hline \multicolumn{7}{|l|}{ Firm size: } \\
\hline$\leq 25$ & -0.238 & 0.015 & $* * *$ & -0.210 & 0.011 & $* * *$ \\
\hline$>25 \& \leq 50$ & -0.182 & 0.015 & $* * *$ & -0.160 & 0.011 & $* * *$ \\
\hline$>50 \& \leq 100$ & -0.094 & 0.015 & $* * *$ & -0.133 & 0.012 & $* * *$ \\
\hline$>100$ & - & - & - & - & - & - \\
\hline \multicolumn{7}{|l|}{ Type of contract: } \\
\hline Open-ended & - & - & - & - & - & - \\
\hline Per-task & -0.053 & 0.005 & $* * *$ & -0.007 & 0.007 & \\
\hline Casual & -0.041 & 0.004 & $* * *$ & -0.047 & 0.005 & $* * *$ \\
\hline Work experience \& training & -0.075 & 0.032 & $* *$ & -0.187 & 0.025 & $* * *$ \\
\hline Interim & 0.042 & 0.013 & $* * *$ & 0.048 & 0.012 & $* * *$ \\
\hline Other temporary & -0.483 & 0.009 & $* * *$ & -0.591 & 0.008 & $* * *$ \\
\hline \multicolumn{7}{|l|}{ Qualification group: } \\
\hline Qual. 1 & 0.446 & 0.010 & $* * *$ & 0.488 & 0.015 & $* * *$ \\
\hline Qual. 2 & 0.251 & 0.006 & $* * *$ & 0.245 & 0.009 & $* * *$ \\
\hline Qual. 3 & 0.113 & 0.007 & $* * *$ & 0.168 & 0.006 & $* * *$ \\
\hline Qual. 4 & 0.071 & 0.004 & $* * *$ & 0.064 & 0.004 & $* * *$ \\
\hline Qual. 5 & - & - & - & - & - & - \\
\hline$\sigma_{u}$ & 0.182 & 0.002 & $* * *$ & 0.185 & 0.002 & $* * *$ \\
\hline$\sigma_{v}$ & 0.357 & 0.001 & $* * *$ & 0.380 & 0.001 & $* * *$ \\
\hline$\rho$ & 0.206 & 0.003 & $* * *$ & 0.192 & 0.004 & $* * *$ \\
\hline $\begin{array}{l}\text { Log likelihood } \\
\mathrm{n} \text { observations } \\
\mathrm{n} \text { firms } \\
\text { Likelihood ratio test }^{\mathrm{a}}\end{array}$ & \multicolumn{3}{|c|}{$\begin{array}{c}-43529.334 \\
95,767 \\
1,016 \\
\chi^{2}(1)=3.3 * 10^{4} \\
\text { Prob } \geq \chi^{2}=0.000\end{array}$} & \multicolumn{3}{|c|}{$\begin{array}{c}-40228.811 \\
77,379 \\
953 \\
\chi^{2}(1)=1.7 * 10^{4} \\
\text { Prob } \geq \chi^{2}=0.000\end{array}$} \\
\hline
\end{tabular}

${ }^{a}$ Denotes likelihood-ratio test, which provides a test for pooled (tobit) estimator against random-effects panel estimator

*** significant at $1 \%$; ** significant at 5\%; * significant at $10 \%$. Regressions also control for years (1998-2003) and regions 
Table 4. Decompositions of gender wage difference between men and women (in logarithms)

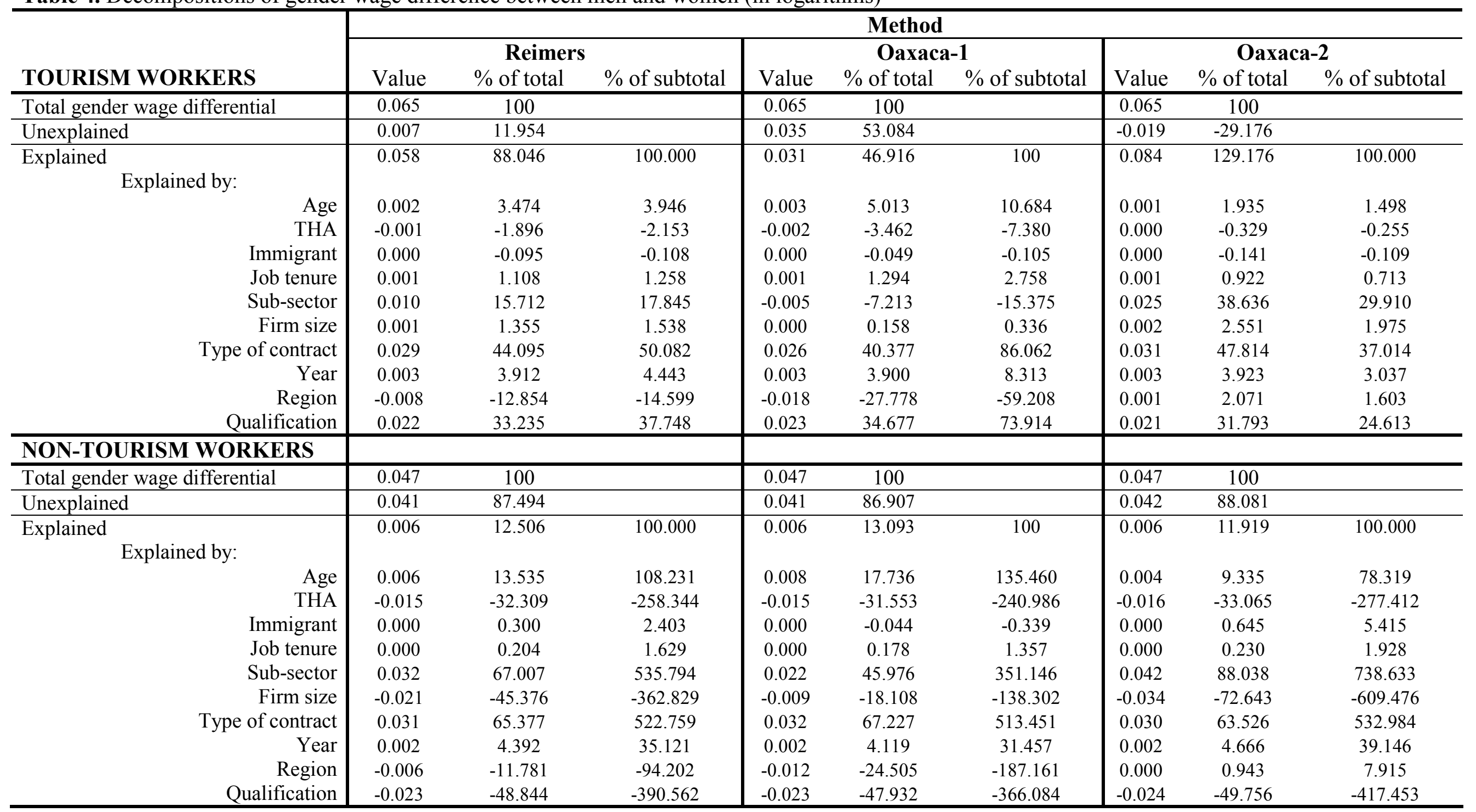

